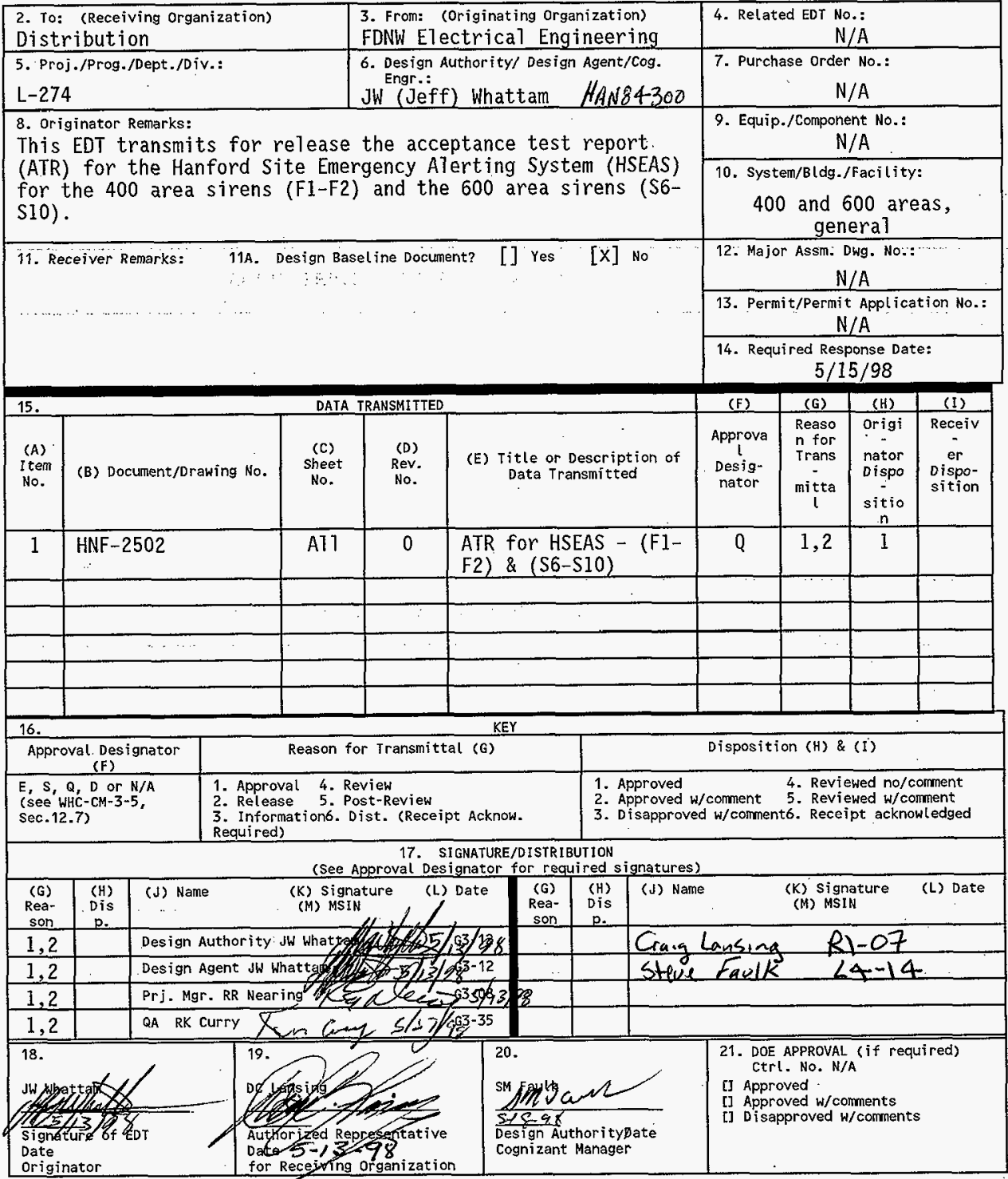

BD-7400-172-2(05/96) GEF097 


\section{ATR-Hanford Site Emergency Alerting System - 400 Area (F1-F2) \& 600 Area (S6-S10)}

JW Whattam

FDNW, Richland, WA 99352

U.S. Department of Energy Contract DE-AC06-96RL13200
EDT/ECN: 618043
Org Code: SF830000
B\&R Code: EW7070201
UC: 600
Charge Code: $F \geq 74 F$
Total Pages: 42

Key Words: HSEAS, Siren, Sirens, Alarm, Alarms, Emergency Notification, Emergency Warning, Columbia River Emergency Alerting System, Hanford Site Emergency Alerting System, 400 Area, 600 Area

Abstract: This document provides the results of the acceptance test procedure performed under document number: HNF-2501, Rev 0 .

TRADEMARK DISCLAIMER. Reference herein to any specific comercial product, process, or service by trade name, trademark, manufacturer, or otherwise, does not necessarily constitute or imply its endorsement, recommendation, or favoring by the United States Government or any agency thereof or its contractors or subcontractors.

Printed in the United States of America. To obtain copies of this document, contact: Document control Services, P.0. Box 950, Mailstop H6-08, Richland WA 99352, Phone (509) 372-2420; Fax (509) 376-4989.
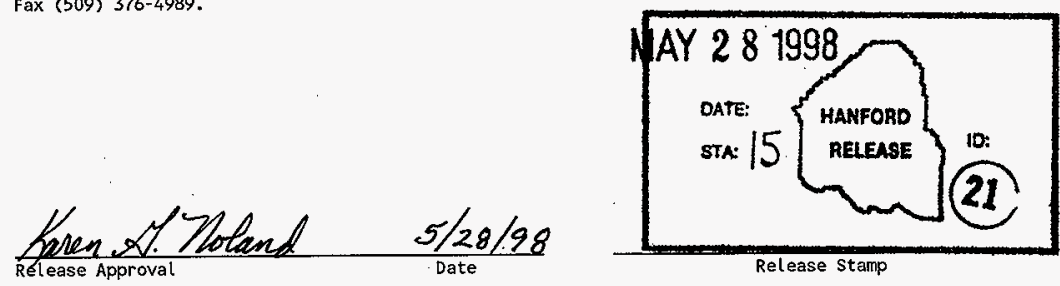

\section{Approved for Public Release}


TEST TITLE HANFORD SITE EMERGENCY ALERTING SYSTEM - 400 AREA (F1-F2) \& 600 AREA (S6-

SIO) SIREN STATIONS, CENTRAL CONTROLLER AND PORTABLE TEST SET

LOCATION $400 \& 600$ AREAS

PROJECT NUMBER L274 WORK ORDER

PROJECT TITLE HANFORD SITE EMERGENCY ALERTING SYSTEM

Prepared By
Fluor Danie]. Northwest

Richland, Washington

For the U.S. Department of Energy

PROCEDURE APPROVAL - See ATP \# HNF-2501, Rev 0 for approvals.

Fluor Daniel Northwest

Lead Engineer, JW Whattam

Date Project Manager, RR Nearing

Date

Lockheed Martin Services, Inc.

$\overline{\text { Quality Assurance, RK Curry }} \overline{\text { Date }}$

DynCorp Tri-Cities Services, Inc.

$\overline{\text { Team Leader, Emergency Preparedness }} \overline{\text { Date }} \overline{\text { EP Specialist, DC Lansing }}$

S.M. FauTk

SES ÚSA, Inc

Vendor Representative, WK Flynn

Date 
HNF-2502, Rev 0

EXECUTION AND TEST APPROVAL,

EXECUTED BY (PRINT, SIGN, \& DATE)
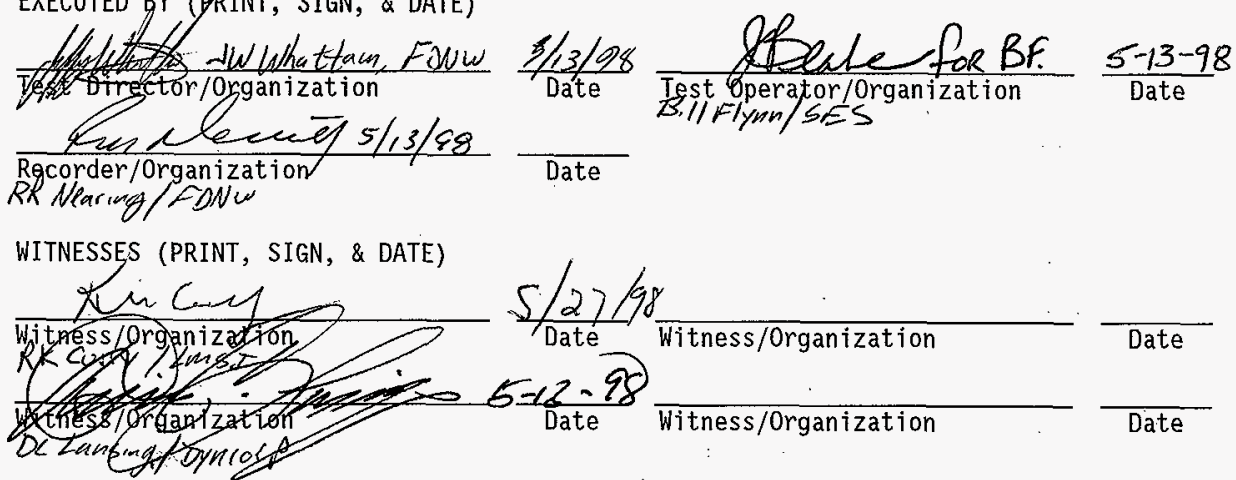

ATE APPROVAL (PRINT, SIGN, \& DATE)

Fluor Daniel Northwest (FDNW)

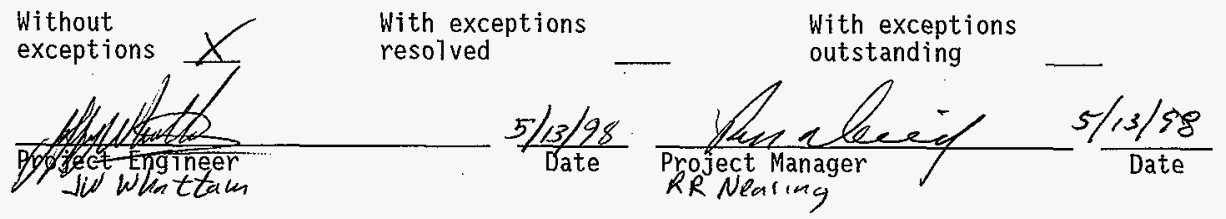

TEST APPROVAL AND ACCEPTANCE (PRINT, SIGN, \& DATE)

Dyncorp Tri-Cities Services, Inc.

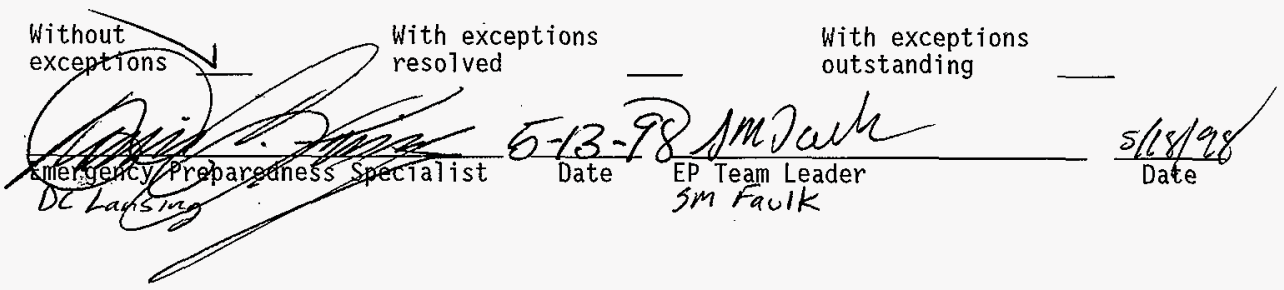

2 
TABLE OF CONTENTS

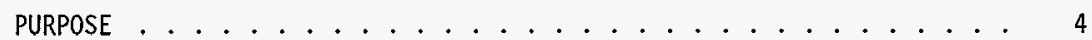
REFERENCES ............................. 4 RESPONSIBILITIES ................................ 4 CHANGE CONTROL ............................. 7

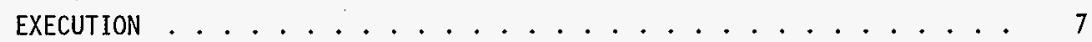
EXCEPTIONS .................................... 8 PREREQUISITES, EQUIPMENT/INSTRUMENTS, ABBREVIATIONS, AND

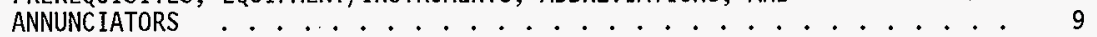
TEST CONDITIONS AND INSTRUCTIONS .................. 10 PHYSICAL INSPECTION - SIREN STATIONS .............. 11 OPERATIONAL TESTING - SIREN STATIONS . . . . . . . . . . . . 13 PHYSICAL INSPECTION - PORTABLE TEST SET PTS-864 . . . . . . . . . 17 OPERATIONAL TESTING - PORTABLE TEST SET PTS-864 . . . . . . . . 17 PHYSICAL INSPECTION - CENTRAL STATION CONTROLLER WDL864PC . . . . 18 OPERATIONAL TESTING - CENTRAL STATION CONTROLLER WDL864PC . . . . 18 
HNF-2502, Rev 0

PURPOSE

This Acceptance Test Procedure has been prepared to demonstrate the Hanford Site Emergency Alerting System functions as required by Specification WHC-S0454, REV 1 and project criteria.

\section{$2.1 \quad$ DRAWINGS}

See specification WHC-S-0454, Rev 1 for reference drawings

2.2 SPECIFICATIONS

WHC-S-0454, Rev 1 Insta1lation Specification For Hanford Site Emergency Alerting System

2.3 ENGINEERING CHANGE NOTICES (ECN)

Prior to final test approval, enter ECNs written against this. ATP.

3.1 GENERAL

Each company or organization participating in this ATP witl designate personnel to assume the responsibilities and duties as defined herein for their respective roles. The designees shall become familiar with this ATP and the systems involved to the extent that they can perform their assigned duties.

3.2 DYNCORP EMERGENCY PREPAREDNESS REPRESENTATIVE

3.2.1 Coordinates testing with the Area Manager and Affected Building Emergency Directors:

3.2.2 Distributes the approved testing schedule before start of testing.

3.2.3 Notifies concerned parties when a change is made in the testing schedule.

3.2.4 Signs Execution and Test Approval page when test is approved and accepted.

3.2.5 Signs Exception Form when exception has been resolved.

3.2.6 Provides a distribution 1 ist for the approved and accepted ATP(ATR). 
3.3 FDNW PROJECT MANAGER

3.3.1 Designates a Test Director.

3.3.2 Notifies the persons supporting the test at least 2 days before the start of testing.

3.3.3 Schedules a dry run when necessary.

3.3.4 Acts as liaison between the participants in acceptance testing.

3.3.5 Schedules and conducts a pretest kickoff meeting with test participants when necessary.

3.3.6 Signs Execution and Test Approval page when test is approved and accepted.

3.3.7 Signs Exception Form when exception has been resolved.

\subsection{TEST DIRECTOR}

3.4.I Coordinates and directs acceptance testing.

3.4.2 Confirms that field testing and inspection of the system or portion of the system to be tested has been completed.

3.4.3 Stops any test which, in his or her judgment, may cause damage to the system until the problem has been resolved.

3.4.4 After verifying there is no adverse impact, may alter the sequence in which systems or subsystems are tested.

3.4.5 Ensures that required environmental conditions are maintained.

3.4.6 If a test is to be suspended for a period of time, ensures that the system is left in a safe mode.

3.4.7 Before restarting suspended test, reverifies the test prerequisites.

3.4.8 Initiates ECNs to document required changes to the ATP.

3.4.9 Reviews recorded data, discrepancies, and exceptions.

3.4.10 0btains information or changes necessary to clear or resolve objections during the performance of the test.

3.4.11 Takes necessary action to clear exceptions to the test. 
3.4.12 Signs Execution and Test Approval page when test has been performed.

3.4.13 Signs Exception Form when exception has been resolved.

3.4.14 Obtains required signatures on the ATP Master prior to reproduction and distribution.

WITNESSES (Provided by Participating Organizations)

3.5.1 Witness the tests.

3.5.2 Review results of testing.

3.5.3 Assist the Test Director when requested.

3.5.4 Sign Execution and Test Approval page when test has been performed.

3.5.5 Sign Exception Form when exception has been resolved.

3.6 RECORDER

3.6.1 Prepares a Field copy from the ATP Master.

3.6.2 Records names of all designated personnel on Field copy of ATP prior to start of testing.

3.6.3 Records test instrument identification numbers and calibration expiration dates, as required.

3.6.4 Initials and dates every test step on the Field copy as it is completed next to the step number or on a data sheet, when provided. Records test data. On data sheets where there is not room for both the initial and date, date may be entered at bottom of column.

3.6.5 Records objections and exceptions on an Exception form. Uses additional Exception forms as needed. Notifies the Test Director at time the objection is made.

3.6.6 Signs Execution and Test Approval page when test has been performed.

3.6.7 After test is finished, assigns alpha numeric page numbers to added data sheets and Exception forms. Records page numbers in the Table of Contents. 
3.6.8 Transfers Field copy entries for each step to the Master in ink or type, signs, and dates. Transmits the completed Master to the Test Director for approval signature routing.

3.6.9 Signs Exception Form when exception has been resolved and transmits to Test Director.

3.7

TEST OPERATOR

3.7.1 Performs test under direction of the Test Director.

3.7.2 Provides 7abor, equipment, and test instruments required for performing tests which have not been designated as being provided by others.

3.7.3 Requests in writing from the Test Director those services, materials, or equipment that have been designated as being supplied by others.

3.7.4 Confirms that all equipment required for performing test will be available at the start of testing.

3.7.5 Signs the Execution and Test Approval page.

3.8 A-E DESIGN ENGINEER AND MANAGER

3.8.1 Evaluate results.

3.8.2 Sign for A-E Approval on Execution and Test Approval page.

CHANGE CONTROL

Required changes to this ATP may be processed by field "red] ine" changes to final acceptance test report with approval from test director. If a need for change is discovered in the course of running the test, the test shali be stopped until the test director approves the required changes and gives notice to proceed. However, this does not prevent the running of another portion of the test unaffected by the change.

Individuals shail carry out their assigned work in a safe manner to protect themselves and others from undue hazards and to prevent damage to property and environment. Facility line managers shall assure the safety of activities within their areas to prevent injury, property damage, or interruption of operation. Performance of test activities shall always include safety and health aspects. 


\subsection{PERFORMANCE}

5.2.1 Perform test following the steps and requirements of this procedure.

5.3.1 Prior to final ATP testing, a pre-ATP shall be performed to verify the system has been installed and is functioning properly to allow time to resolve any system problems prior to final ATP. This pre-ATP shall consist of performing all of section 9 and part of section 10 through step 10.1.26. These steps will not require the full complement of witnesses as the finat ATP. Instead, these steps need only be performed in the presence of the vendor representative, FDNW project engineer, and the LMSI quality assurance engineer. These steps will be checked off of the data sheet for each siren station tested and will not need to be repeated during final ATP. However, the checked off steps will become part of the final data sheet for each siren station tested.

Exceptions to the required test results are sequentially numbered and recorded on individual Exception forms. This enables case-by-case resolution and approval of each exception.

Errors/exceptions in the ATP itself shal1 NOT be processed as test exceptions (see Section 4 CHANGE CONTROL).

6.2 RECORDING

6.2.1 Number each exception sequentially as it occurs and record it on an Exception Form (KEH-428).

6.2.2 Enter name and organization of objecting party for each exception.

6.2.3 Enter planned action to resolve each exception when such determination is made.

\subsection{RETEST/RESOLUTION}

Record the action taken to resolve each exception. Action taken may not be the same as planned action. 
6.3.1 When action taken results in an acceptable retest, sign and date Retest Execution and Acceptance section of the Exception Form.

6.3.2 When action taken does not involve an acceptable retest, strike out the Retest Execution and Acceptance section of the Exception Form.

6.4 APPROVAL AND ACCEPTANCE

The customer provides final approval and acceptance of exceptions by checking one of the following on Exception Form:

6.4.1 Retest Approved and Accepted: Applicable when Retest Execution and Acceptance section is completed.

6.4.2 Exception Accepted-As-Is: Requires detailed explanation.

6.4.3 Other: Requires detailed explanation.

The customer signs and dates the Exception Form and obtains other customer internal approvals, if required.

6.5 DISTRIBUTION

A copy of the approved Exception Form is distributed to each participant. The signed original is attached to the ATP Master.

PREREQUISITES, EQUIPMENT/INSTRUMENTS, ABBREVIATIONS, AND ANNUNCIATORS

\subsection{PREREQUISITES}

The following conditions shall exist at start of testing for that portion of the system being tested.

7.1.1 Systems have been inspected for compliance with construction documents.

7.1.2 Reference documents (including this ATP) have been verified for correct revision number and outstanding ECNs.

7.1.3 A Prejob Safety Analysis has been prepared and a Prejob Safety Meeting has been conducted.

7.1.4 Equipment/Instruments identified in Para 7.2 are available to perform the test and have a valid calibration stamp attached, if required by the QA engineer, or have been field calibrated. Test instrument identification numbers and calibration expiration dates, where required have been recorded in Para 7.2 . 
HNF-2502, Rev 0

7.1.5 Voice communications are available between 200 Area Patrol operations Center (POC) and local test sites.

7.2 EQUIPMENT/INSTRUMENTS

Supplied by Test Operator unless otherwise noted.

7.2.1 Voltohmmeters (VOM):

Instrument No. Expiration Date

Field Calibrated: (QA engineer initials for acceptance)

\subsubsection{Noise Dosimeter (Sound Level Meter):}

Instrument No. Expiration Date

Field Calibrated: (QA engineer initials for acceptance)

7.3 ABBREVIATIONS

ECN Engineering Change Notice

TEST CONDITIONS AND INSTRUCTIONS

8.1 Instruction steps shall be performed for each siren station as applicable. The data for these steps shat1 be recorded on the data sheet to be provided by the test director. Each data sheet shall be numbered sequentially beginning with $A 1$. Those steps not required to be performed for a given station shall be so noted on the data sheet. Each step completed shall be initialed and dated on the data sheet by the recorder. Thus, this ATP shal1 serve as the master instruction Tist with a separate data sheet prepared for each individual siren station to be tested.

8.2 An Emergency Preparedness (EP) representative shall initial and date the upper left hand corner of each data sheet indicating that the proper notifications have been completed and it is acceptable to test that station. The EP representative shall indicate on the test data sheet below his/her initials the acceptable dates for testing that station. This date does not have to be a single day but can be a block of days to allow the test director to coordinate scheduling of several sirens on different days.

8.3 For those steps requiring verification of values such as fuse sizes, voltage levels, or battery ratings, the recorder shall record in the appropriate columns on the data sheet, the step number, the item to be tested, the value anticipated, and the value found during testing. The recorder will then initial and date this step. 
8.4 After testing has been completed for each siren station, and all of the exceptions have been resolved, the recorder shall initial and date the upper right hand corner of the data sheet for that station indicating testing for that station is concluded.

\section{PHYSICAL INSPECTION - SIREN STATIONS}

The purpose of the following tests is to confirm that each individual siren station consisting of a silo with housed electronics and elevator, a pole with siren cell head and solar mast are in good working order and installed per design and project criteria before operational testing is initiated.

\subsection{SILO ENCLOSURE}

9.1.1 Locate key activation switch, insert key, rotate to up position. Engage until cabinet is fully exposed with battery compartment at service leve?. Verify limit switch disengages motor and silo stops, then turn key to center position.

9.1.2 Verify safety pin is available and insert into slot. Open battery compartment(s). Check battery leads are not damaged. Check terminals are tight (perform "tug test"), confirm all battery terminals are clean and confirm silicone coating is applied to all terminals.

9.1.3 Check batteries for uniform rating and type. All battery ratings must be of the same voltage and ampere rating.

9.1.4 Close battery compartment(s). Remove safety pin and return to storage slot.

9.1.5 Locate AC connection terminal on outside of silo enclosure and verify cover opens and closes without obstruction.

9.1.6 Locate fuse in key activation switch and verify value is 20 ampere and cover opens and closes without obstruction.

9.1.7. Confirm silo cap cover insulated.

9.1.8 Confirm enclosure sealed.

9.1.9 Confirm cable clearance by checking wire loop, no crimping or snag or damage to the cable or possible obstructions that may interfere with free movement of cable. Examine a11 wiring harnesses for chafing. Verify wiring terminations for tightness. 
HNF-2502, ReV 0

9.1.10. Verify ground wire lug is firmly attached to silo and ground wire is tight. Verify ground wire is secured to monopole.

9.1.11 Confirm rail on which cabinet rides is secure and al1 fasteners are tight securing instrument cabinet to assemb1y.

9.1.12 Confirm hydrogen vent is clear to atmosphere.

9.1.13 Lower silo until siren control cabinet is at service level.

9.2 SIREN CABINET

9.2.1 Open cabinet case assembly, secure door lock in open position with latch, open internal module panel by removing screws located in front.

9.2.2 Pull main fuse disconnect, confirm that fuse rating is per design and prongs have lubrication and are clean, then reinsert disconnect in the off position.

9.2.3 Turn silo key to raise silo and verify motor still operates with main fuse disconnect off. Turn off orange battery switch and confirm silo motor does not operate, then turn battery switch on. Return silo to original location and turn key off. Return main fuse disconnect to the on position.

9.2.4 Confirm \& inspect $A C$ outlet, fuse/breaker and surge suppression equipment.

9.2.5 Check all vent screens and confirm clean.

9.2.6 Confirm that mounting hardware of all components are secure to cabinet.

9.2.7 Confirm AC service plug/charger fuse is installed.

9.2.8 Check electrical \& Tightning grounding installed per design.

9.2.9 Observe antenna radio connections and confirm all are secure.

9.2.10 Confirm siren case assembly controller is flush and secure to inside face panel.

9.2.11 Leave silo up for operational testing or close al1 compartments, lower silo, and raise later if operational 
HNF-2502, Rev 0

testing is to be performed on a separate shift.

\section{$9.3 \quad$ MONOPOLE}

9.3.1 Inspect base nuts \& bolts and verify proper torque or compression per drawing requirements.

9.3.2 Confirm solar array winch is secure to mounting plate and not damaged.

9.3.3 Inspect solar array cable assembly and trackway and verify no damage or obstructions exist.

9.3.4 Open pole wireway hatch, and verify conduit is sealed.

9.3.5 Inspect speaker cluster. Confirm that all bolting is tight without gaps between cells and bird screens are in place (this step may be performed prior to erecting pole).

\subsection{SOLAR ARRAY}

9.4.1 Connect dodger setup to port on solar winch housing.

9.4.2 Attach dodger cables to appropriate 12 Vdc power supply. Stand away from solar assembly arm and operate dodger to lower solar panels to service level.

9.4.3 Verify mechanical locking arm is functioning properly. Confirm all solar cell panels are tight and wired securely.

9.4.4 Stand away from solar assembly arm and operate dodger to raise panels to the full upright position. Verify mast seats correctly into supports, and disconnect dodger setup.

\section{OPERATIONAL TESTING - SIREN STATIONS}

The purpose of this test is to confirm each siren station operates as intended by design criteria.

\subsection{SIREN CABINET}

10.1.1 Ensure silo is at proper height for local siren controller pane 7 access. Open siren cabinet and secure latch (if continuation of section 9 , then silo should already be at the proper height with cabinet open).

10.1.2 Open disconnect connecting solar panels to charging unit and test solar array output voltage by connecting DC volt 
meter to connection points. Output should read greater than $26 V$ DC (note weather conditions as sunny or not).

10.1.3 With solar panels still disconnected, verify battery voltage range 24-30 VDC by using a DC volt meter at connection points. Close disconnect to re-establish solar panel connection to charging unit.

10.1.4 Confirm power up LED indicator is 7 it.

10.1.5 Confirm 30-sec. power down indicator is not lit.

10.1.6 For the portion of testing requiring the removal and replacement of fuses, deenergize system as necessary to avoid damage. Remove fuses from all amplifiers. Verify a11 are 30 ampere. Verify FUT1 LED and Part. LED go out (not the individual amplifier LEDs, these wil1 be tested later, instead watch the main LEDs on the control board).

10.1.7 Replace fuse into amplifier number one and verify Part. LED is lit and Full LED remains out.

10.1.8 Perform PA test using local microphone and announce "Test One."

10.1.9 Remove fuse and verify Part. LED goes out.

10.1.10 Repeat steps 10.1.6 through 10.1 .9 for all amplifiers to be tested.

10.1.11 Ensure al1 amplifier fuses have been removed.

10.1.12 Turn battery switch on/off as necessary to controT MDK setup. Plug MDK set into socket on panel face.

10.1.13 Confirm Timer Set LED on MDK is 1 it

10.1.14 Press program key on MDK and confirm area code and siren code are displayed on MDK test set.

10.1.15 Unplug MDK set.

10.1.16 Remove phoenix type connector from tone generator board (located upper right on top most enclosure).

10.1.17 Connect external speaker to pins TG-1 and TG-2 (use of telephone service technician style monitor set is acceptable). 
10.1.18 From portable test set, select S0 and G3. Type in siren address for siren being tested and select MSGl (key number 1) and then shift and send to initiate message. (If portable test set is not functioning, this step may be performed from the base station per the direction of the test director).

10.1.19 Listen and verify message output is correct. Repeat step 10.1.18 to verify each message to be tested.

10.1.20 Disconnect speaker, reattach phoenix type connector, and reinstall amplifier fuses.

10.1.21 Locate indicator LED on solar regulator and verify 1 it

10.1.22 Turn switch to off position and verify LED is off.

10.1.23 Turn switch back on and verify LED is on.

10.1.24 Perform SI-TEST using front panel button to verify system has been returned to normal operating condition (if final ATP is to be performed on the same day, skip to step 10.1.26).

10.1.25 Close all compartments and lower silo. Verify silo cap seats properly and limit switch disengages motor.

10.1.26 Verify siren base station computer $\log$ has received an intrusion alarm from each site tested. End of Pre-ATP (continue with step 10.1.27 when final ATP is to be completed).

10.1.27 Bring siren cabinet to service level (if final ATP is performed at the same time as the pre-ATP, then siren cabinet is already at service level). At the Manual Test Controller ESC864: connect microphone, turn sound level knob on ESC864 to full position. Key microphone and announce "This is a test." Maintain microphone setup for remainder of testing.

10.1.28 Locate CTipping LED's. Confirm 1it during microphone use, and siren activation as flicking on and off.

10.1.29 Starting on left of front pane1, there are openings for al1 power amplifier indicators. These will be lit (for those amplifiers used) as sound is projected and is processed. Verify using microphone announcement. Repeat if necessary. 
10.1.30 Clear button indicator should be located in case accidental activation should occur. Push at any time throughout this test to quiet siren if necessary.

10.1.31 Place acoustic monitor near silo station and prepare to record decibel level for alarm testing. Record maximum reading during testing using the ' $\mathrm{C}$ ' weighted scale. If reading rises above $115 \mathrm{dBc}$, clear alarm at once, note exception and proceed to next alarm test. Place second acoustic monitor at radius of expected siren coverage to record background sound level and individual alarm levels. Confirm monitors are in place before proceeding.

10.1.32 Use microphone to announce "This is a test of the Hanford Site Emergency Alerting System. Several alarms will sound following this message. No action is required. This is only a test."

10.1.33 Find WAIL button (not WAIL 5 SEC) and press. Indicator wi11 be 1 it when activated. Wait $10-15$ seconds, then press CLEAR button.

10.1.34 Repeat steps 10.1.33 for ATK a1 arm.

10.1.35 Repeat steps 10.1.33 for ALRT alarm.

10.1.36 Repeat steps 10.1.33 for AIRHORN a1 arm.

10.1.37 Repeat steps 10.1.33 for HI-LO alarm.

10.1.38 Repeat steps 10.1.33 for WHP alarm.

10.1.39 Repeat steps 10.1.33 for WAIL 5 SEC alarm.

10.1.40 Engage Silent-Test button. Indicator wil1 1ight when activated. Check LED indicators in side of pane 7 for 1 it condition. Confirm system OK.

10.1.41 Lift latch on outer door and close securely. Look around for any tools or test meters and remove from enclosure. Activate silo key by turning to down position. Verify cap seats properly and limit switch disengages motor. Return system to standby operation, remove key and close key cover.

10.1.42 Confirm that silo is closed and solar panel mechanism is secure and in place. 
HNF-2502, Rev 0

11 PHYSICAL INSPECTION - PORTABLE TEST SET PTS-864

The purpose of the following tests are to insure that the portable test set, PTS-864, is in good working order prior to operational testing. NOTE:

operator must keep test set away from siren speaker cells as needed to avoid feedback.

\section{$11.1 \quad$ PTS-864 PORTABLE TEST SET}

11.1.1 Confirm suitcase is not damaged, open latch locks, and raise antenna.

\section{OPERATIONAL TESTING - PORTABLE TEST SET PTS-864}

The purpose of the following tests are to confirm the PTS-864 Portable Test Set operates as intended by the design criteria. This test can only be used to activate one siren or a group of sirens within radio reception area.

\subsection{PORTABLE TEST SET PTS-864}

12.1.1 Verify siren spotters are in location with at least one spotter at siren station to be tested. Push on/off switch to on and confirm display for status. It should show date and time. Verify SYS and TIME LED are 1it.

12.1.2 Depress SYS push button. Depress So push button. Verify SO LED is on.

12.1.3 Depress GO push button and verify LED is on.

12.1.4 Enter siren station address (or all call address for those stations to be tested simultaneously) on hex keypad. Press PA button (\#4) on hex keypad. Press SHIFT and SEND buttons. Key microphone and announce "This is a test of the Hanford Site Emergency Alerting System. An alarm will sound following this message. No action is required. This is only a test."

12.1.5 Press CLR button to reset buffer.

12.1.6 Enter siren station address (or all call address for those stations to be tested simultaneous7y) on hex keypad. Press WAIL button. Press SHIFT and SEND buttons. Alarm should sound at all siren stations selected. Verify with siren spotters. After three cycles, alarm should complete. If it continues, press CLEAR then SHIFT then SEND.

12.1.7 Press CLR button to reset buffer. 
12.1.8 Turn off test set by pressing activation button again, put down antenna, check for any obstructions and close 7 id of suitcase securely with lock latches.

PHYSICAL INSPECTION - CENTRAL STATION CONTROLLER WDL864PC

The purpose of the following tests are to confirm the Central Station WDL864PC Controller is in good working order prior to initiating operational testing.

13.1

CENTRAL STATION CONTROLLER WDL864PC

13.1.1 Confirm al1 components, UPS, computer, printer are wired and cabled together on cart and system is ready for testing.

13.1.2 Confirm that no disks are in floppy drive.

13.1.3 Turn on all components and verify indicator power lights are on.

OPERATIONAL TESTING - CENTRAL STATION CONTROLLER WDL864PC

The purpose of the following test is to confirm the Central Station Controller WDL864PC operates as intended by design criteria. (This test may be run as a general all call test if enough spotters are available for each station to be tested.)

14.1 CENTRAL STATION CONTROLLER WDL864PC

14.1.1 Verify siren spotters are in location with at least one spotter at each siren station to be tested.

14.1.2 If screen is at not at cail key menu, exit all screens unti 1 back at main menu screen, then select WARNING and then CALL KEY to enter menu.

14.1.3 Select appropriate test icon for sirens to be tested and follow instructions to activate.

14.1.4 Check with field spotters to verify test PA announcement is being sent, a Tarm is sounding, and test conclusion PA announcement is sounding.

14.1.5 Verify action is logged on screen.

14.1.6 Return to main menu. From main menu, select STATUS then press ENTER. Select call key menu. Select Silent test icon (this will run a silent test on all sirens - making sure entire grid is functioning properly). Select SEND then 
HNF-2502, Rev 0

press ENTER. Verify Silent test is run and logged on screen.

14.1.7 Return to main menu. Select WARNING then CALL KEY. Ca11 in spotters. This concludes testing. 


\begin{tabular}{|c|c|c|c|c|}
\hline \multirow{2}{*}{\multicolumn{2}{|c|}{ Approved fosting: }} & & \multirow{3}{*}{$\begin{array}{l}\text { Testing Complete: } \\
\text { (Recorder's Initials) } \\
\end{array}$} & \multirow{3}{*}{$\frac{\text { Resths }}{\text { ReN At }}$} \\
\hline & & & & \\
\hline (EP.Initials) & & & & \\
\hline & & & & \\
\hline STEP & VALUE ANTICIPATED & VALUEMEASURED & COMPLETED & DATE \\
\hline & (Where needed) & (Where needed) & (Recorder's Initials) & \\
\hline & & & & \\
\hline PRE-ATP & & & & \\
\hline 9.1 Silo Enclosure & & & Ren & $4 / 15 / 98$ \\
\hline 9.1 .1 & & & FR् & $4 / 15 / 98$ \\
\hline 9.1 .2 & & & ERA & \\
\hline 9.1 .3 & $6 \mathrm{~V}, 180 \mathrm{amp}$-hour & & DRM & \\
\hline 9.1 .4 & & & Reat & \\
\hline 9.1 .5 & 5 Rind alusles & & $R R N$ & \\
\hline 9.1 .6 & 20 Ampere & & RRM & \\
\hline 9.1 .7 & & & $R R M$ & \\
\hline 9.1 .8 & & & RRA & \\
\hline 9.1 .9 & & & RRM & \\
\hline 9.1 .10 & & & $R R M$ & \\
\hline 9.1 .11 & & & $2 \sec$ & \\
\hline 9.1 .12 & & & RnN & \\
\hline 9.1 .13 & & & RRA & \\
\hline 9.2 Siren Cabinet & & & $R R A$ & \\
\hline 9.2 .1 & & & $12 R M$ & \\
\hline$\overline{9.2 .2}$ & 200 ampere & & $R R N$ & \\
\hline 9.2 .3 & & & $R R M$ & \\
\hline 9.2 .4 & & & $\operatorname{RRN}$ & \\
\hline 9.2 .5 & & & Rea & \\
\hline 9.2 .6 & & & $R \times a$ & \\
\hline 9.2 .7 & & & $R R M$ & \\
\hline 9.2 .8 & & & RRM & \\
\hline 9.2 .9 & & & $R R M$ & \\
\hline 9.2 .10 & & & RRM & \\
\hline 9.2 .11 & & & $R R A$ & $4 / 15 \sqrt{28}$ \\
\hline 9.3 Monopole & & & REN & \\
\hline 9.3 .1 & & & BRA & \\
\hline 9.3 .2 & & & $R R N$ & \\
\hline 9.3 .3 & & & $R R A$ & \\
\hline 9.3 .4 & & 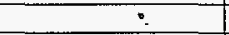 & 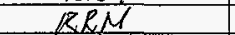 & \\
\hline 9.3 .5 & & & RRM & \\
\hline 9.4 Solar Array & & & RRO & \\
\hline 9.4 .1 & & & REN & \\
\hline 9.4 .2 & & & RRप & \\
\hline 9.4 .3 & & & $R R M$ & \\
\hline 9.4 .4 & & & $R / 2 M$ & 4) $15 / \sqrt[38]{ }$ \\
\hline 10.1 Siren Cabinet & & & ERN & \\
\hline 10.1 .1 & & & $2 \Omega N$ & \\
\hline 10.1 .2 & $>26 \mathrm{VDC}($ up to $45 \mathrm{~V})$ & $4 \vee V D$ & RMN & \\
\hline 10.1 .3 & $24-30 \vee D C$ & $262 \times 10$ & $R R M$ & \\
\hline 10.1 .4 & & & $R R M$ & T \\
\hline 10.1 .5 & & & RRM & 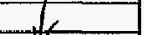 \\
\hline 10.1 .6 & 30 ampere & & REN & \\
\hline 10.1.7 & & & $R R N$ & 4) $15 / 48$ \\
\hline
\end{tabular}


DATA SHEET FOR: $F \mid$

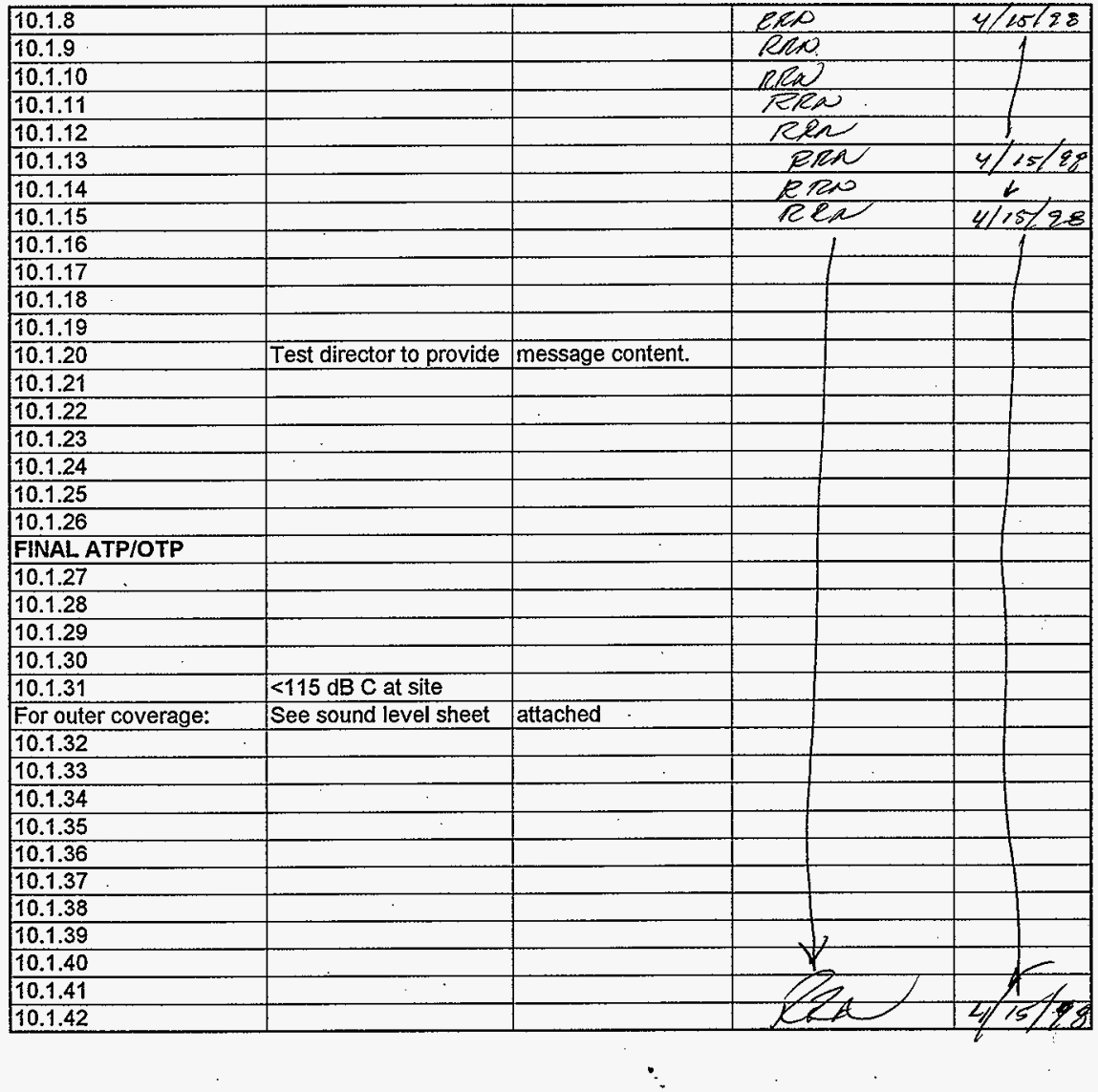




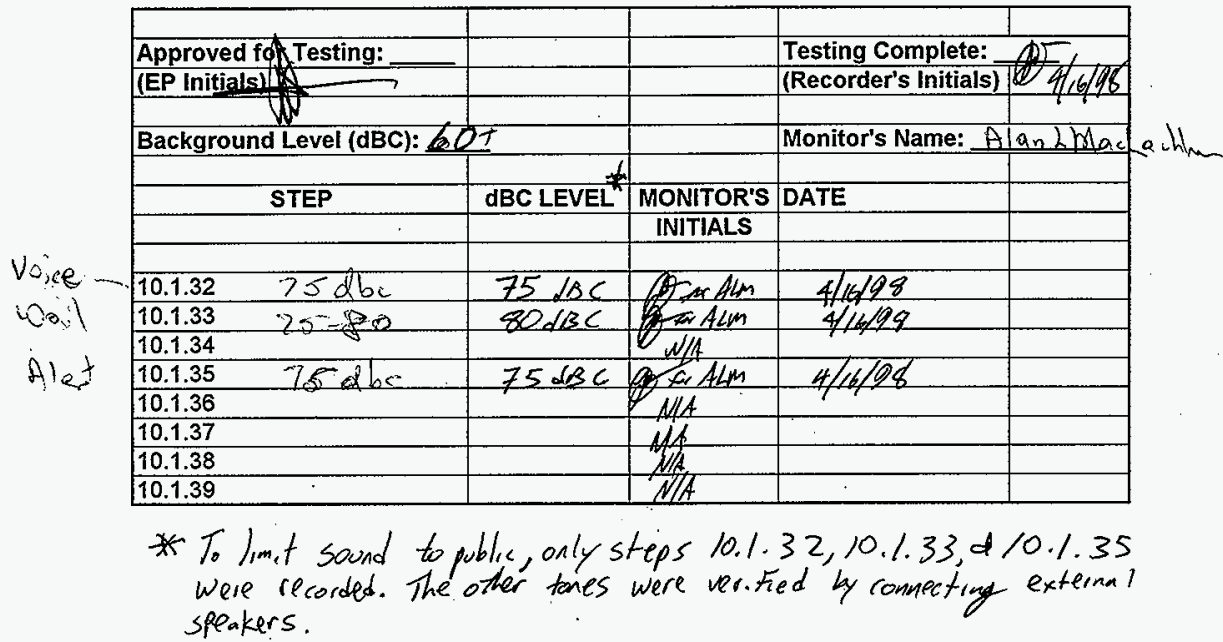

Page: $A 3$ of $2 Z$ 


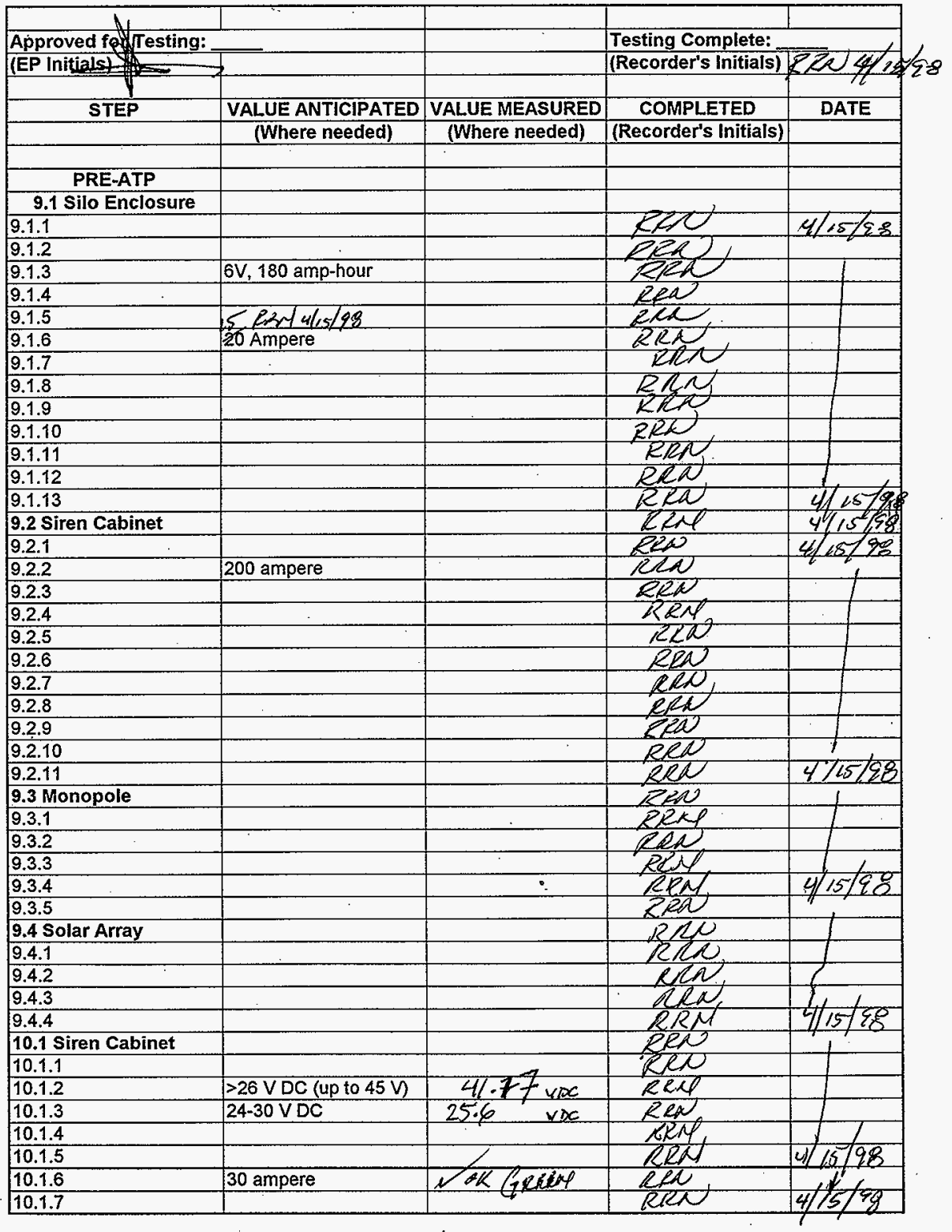




\begin{tabular}{|c|c|c|c|c|}
\hline \multirow{2}{*}{\multicolumn{5}{|c|}{$\frac{R R A}{R I N}$}} \\
\hline & & & & \\
\hline \multicolumn{5}{|c|}{ RRad } \\
\hline 10.1.11 & & & Con & \\
\hline \multirow{2}{*}{\multicolumn{5}{|c|}{\begin{tabular}{|l|l|}
10.1 .12 \\
10.1 .13
\end{tabular}}} \\
\hline & & & & \\
\hline \multicolumn{5}{|c|}{ 10.1.14 , $10 b+0<2$} \\
\hline \multicolumn{5}{|c|}{ 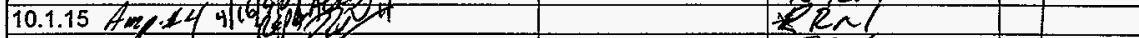 } \\
\hline \multicolumn{5}{|c|}{ 10.1.16 } \\
\hline \multirow{2}{*}{\multicolumn{5}{|c|}{\begin{tabular}{|l|}
10.1 .17 \\
10.1 .18
\end{tabular}}} \\
\hline & & & & \\
\hline \multicolumn{5}{|l|}{$\frac{10.1 .18}{10.1 .19}$} \\
\hline 10.1 .20 & Test director to provide & message content. & RRN & \\
\hline 10.1 .21 & & & $12 R, 8$ & \\
\hline \multicolumn{5}{|c|}{ Rizu } \\
\hline \multicolumn{5}{|c|}{$R n N$} \\
\hline \multicolumn{5}{|c|}{$R R N$} \\
\hline \multicolumn{5}{|c|}{$212 \pi$} \\
\hline 10.1 .26 & & & $\mathbb{R} 2 x$ & 4) $15 / 98$ \\
\hline \multicolumn{5}{|l|}{ FINAL ATP/OTP } \\
\hline \multirow{2}{*}{\multicolumn{5}{|c|}{10.1 .27}} \\
\hline$\frac{10.1 .28}{10.1 .29}$ & & & & \\
\hline \multirow{2}{*}{\multicolumn{5}{|c|}{\begin{tabular}{|l|}
10.1 .29 \\
10.1 .30
\end{tabular}}} \\
\hline & & & & \\
\hline 10.1 .31 & $<115 \mathrm{~dB} C$ at site & & & \\
\hline For outer coverage: & See sound level sheet & attached & & \\
\hline \multicolumn{5}{|l|}{10.1 .32} \\
\hline \multirow{2}{*}{\multicolumn{5}{|c|}{$\frac{10.1 .33}{10134}$}} \\
\hline & & & & \\
\hline \multicolumn{5}{|l|}{\begin{tabular}{|l|}
10.1 .35 \\
10.36
\end{tabular}} \\
\hline \multirow{2}{*}{\multicolumn{5}{|c|}{\begin{tabular}{|l|}
10.1 .36 \\
10.37
\end{tabular}}} \\
\hline \multirow{2}{*}{\multicolumn{3}{|c|}{$\frac{10.1 .37}{10.1 .38}$}} & & \\
\hline \multirow{2}{*}{\multicolumn{5}{|c|}{$\frac{10.1 .30}{10.1 .39}$}} \\
\hline & & & & \\
\hline \multicolumn{5}{|l|}{10.1 .40} \\
\hline \multicolumn{5}{|l|}{10.1 .41} \\
\hline 10.1 .42 & & & Rith & $4 / 15 / 40$ \\
\hline
\end{tabular}




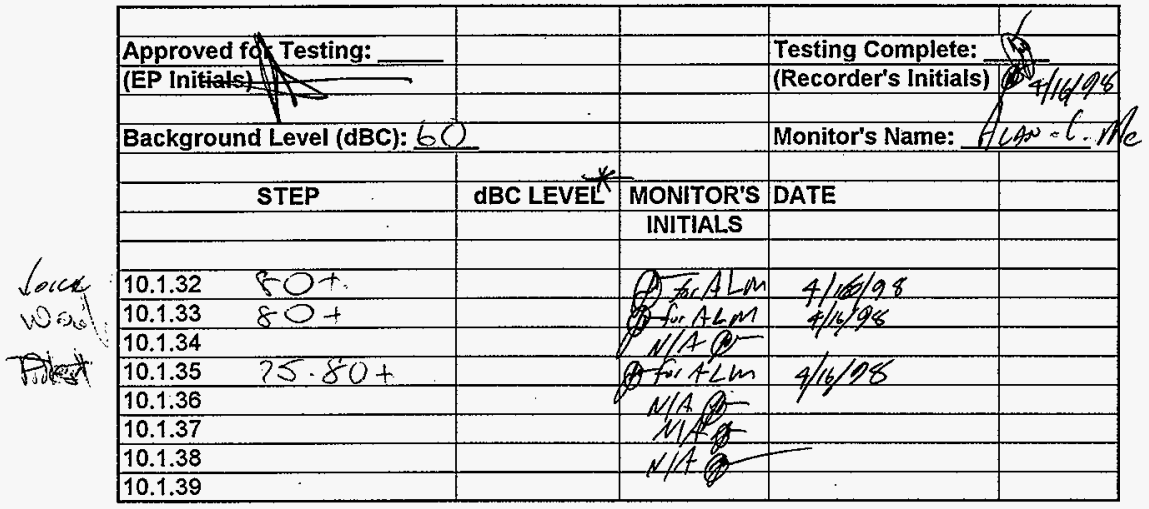

* To limit sound to public, only stepsw1.32,10.1.33, \& 10.1 .35 were recorded. The other tones were ves.firl by comecting extermalspenter. 


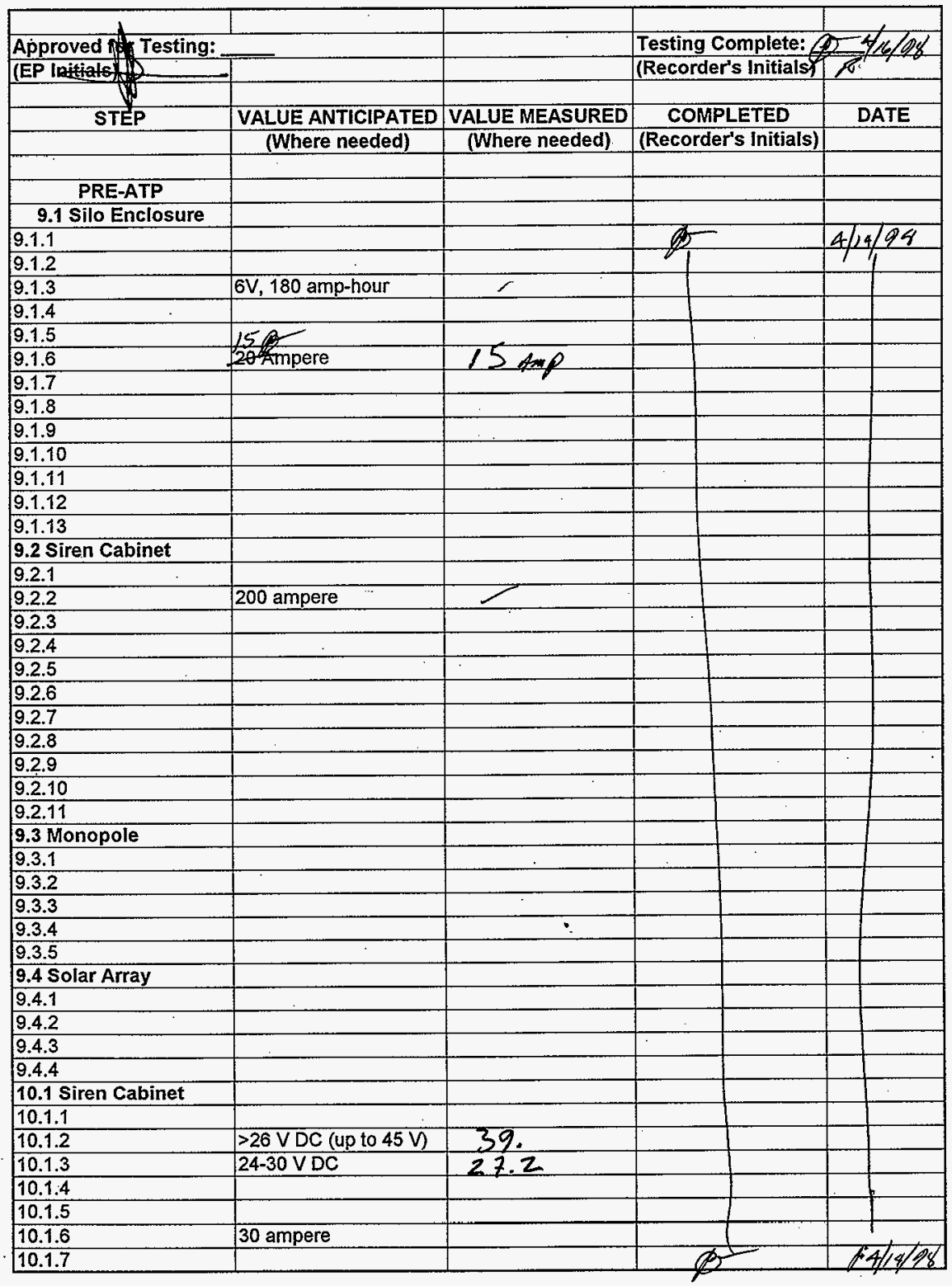


DATA SHEET FOR: 56

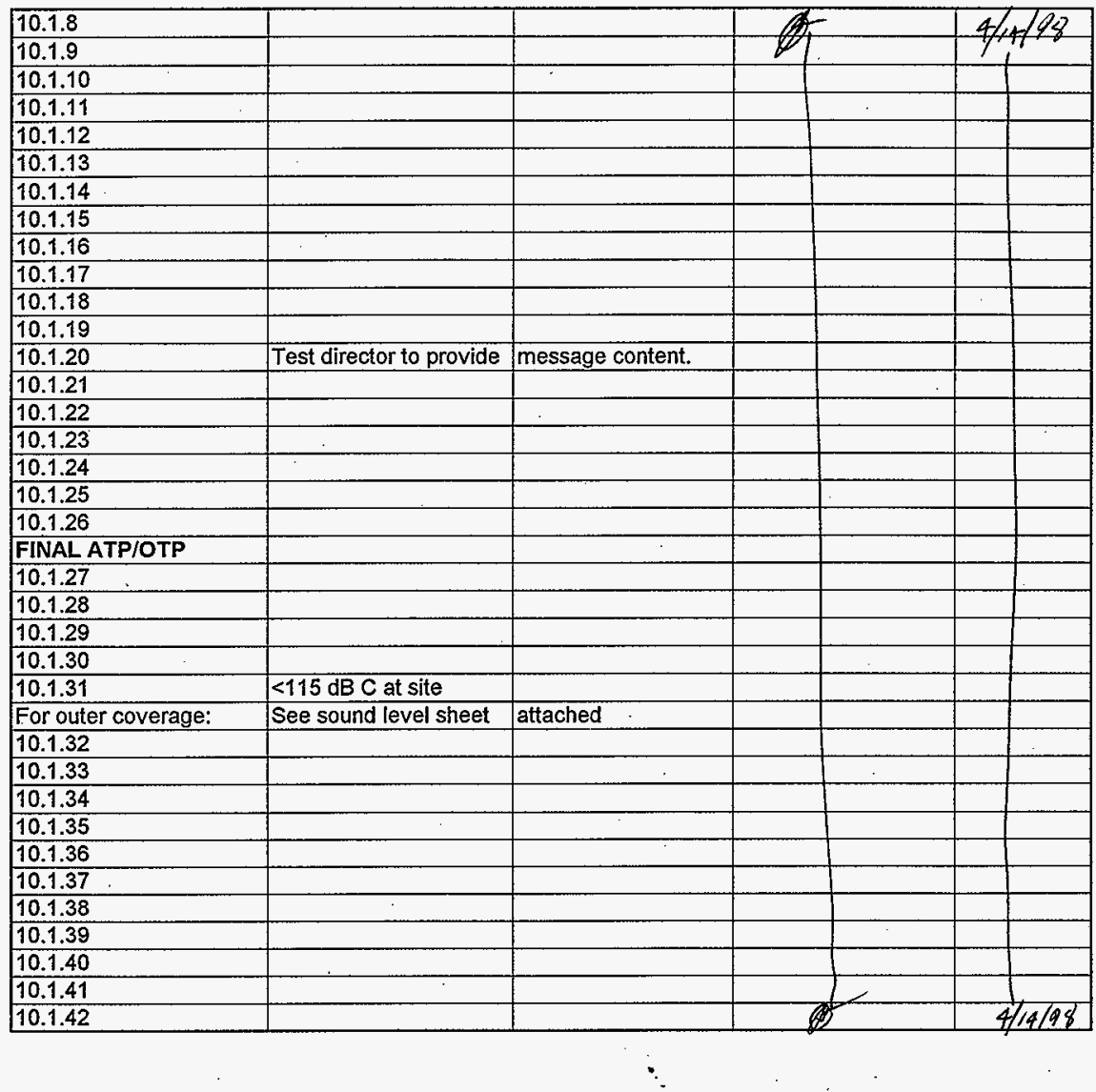


SOUND LEVEL SHEET FOR: 56

kw $\mathrm{HNF}$ HNF-SD-L274-ATR-002, Rev 0

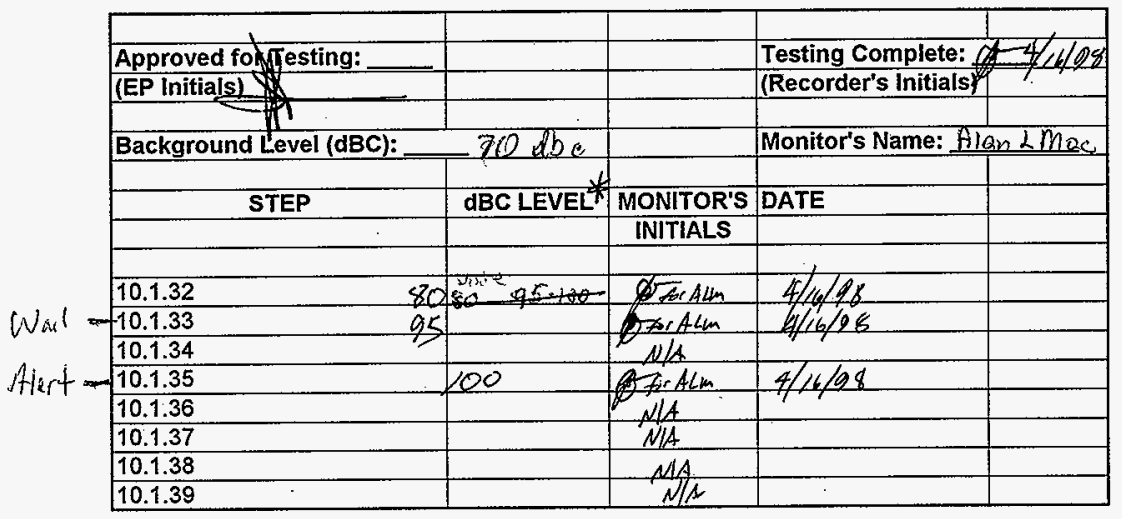

* See note on page A3.

ATR2W.XLS, 3/21/97

Page: 40 of $Z 2$ 
DATA SHEET FOR: 650857

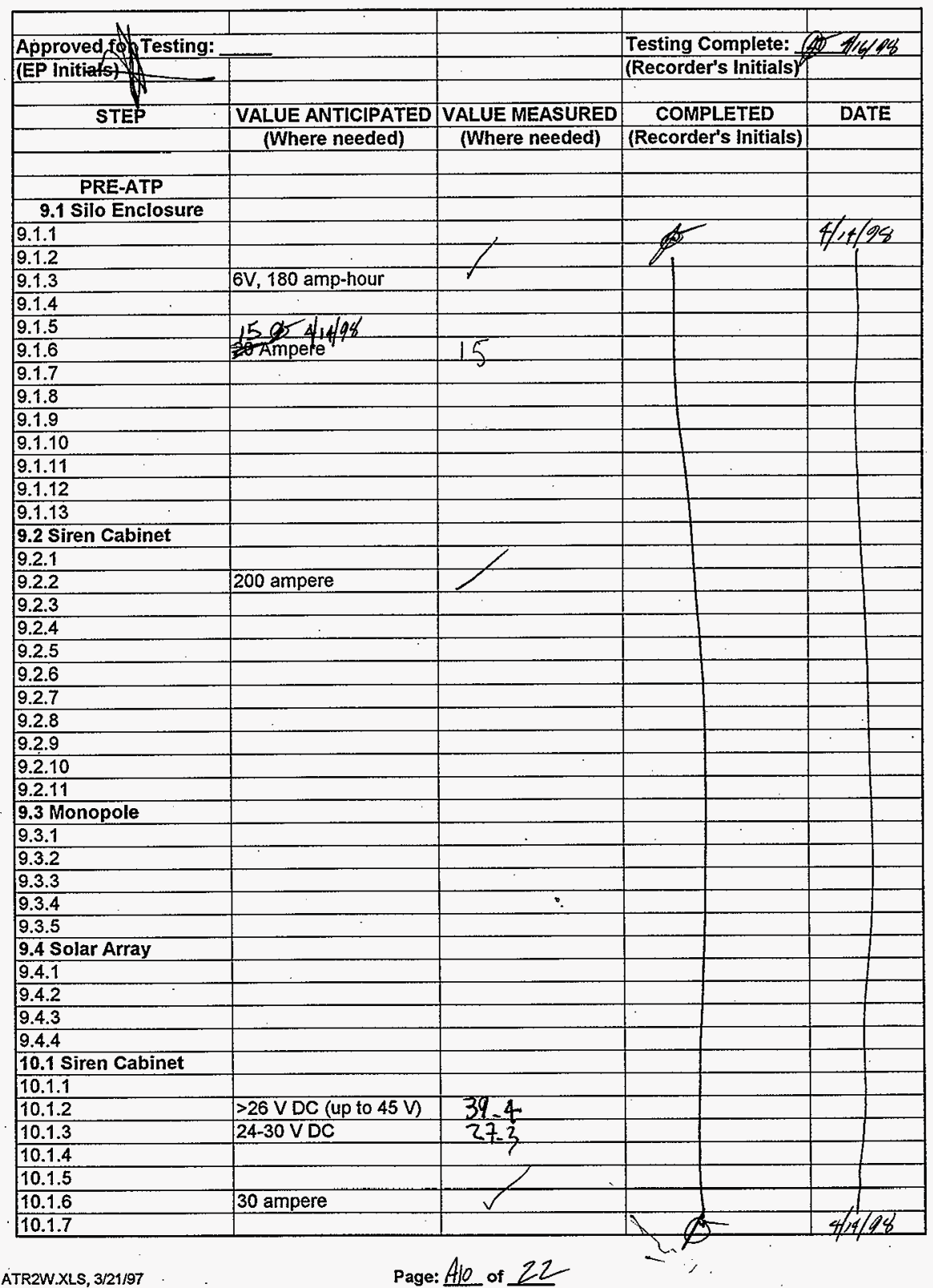




\begin{tabular}{|c|c|c|c|c|}
\hline \multirow{2}{*}{\multicolumn{5}{|c|}{\begin{tabular}{|l|}
10.1 .8 \\
10.1 .9 \\
\end{tabular}}} \\
\hline & & & & \\
\hline \multicolumn{5}{|l|}{10.1 .10} \\
\hline \multicolumn{5}{|l|}{10.1 .11} \\
\hline \multicolumn{5}{|l|}{10.1 .12} \\
\hline \multicolumn{5}{|l|}{10.1 .13} \\
\hline \multicolumn{5}{|l|}{10.1 .14} \\
\hline \multicolumn{5}{|l|}{10.1 .15} \\
\hline \multicolumn{5}{|l|}{10.1 .16} \\
\hline \multicolumn{5}{|l|}{ 10.1.17 } \\
\hline \multicolumn{5}{|l|}{10.1 .18} \\
\hline \multicolumn{5}{|l|}{10.1 .19} \\
\hline 10.1 .20 & Test director to provide & message content. & & \\
\hline \multicolumn{5}{|l|}{10.1 .21} \\
\hline \multicolumn{5}{|l|}{10.1 .22} \\
\hline \multirow{2}{*}{\multicolumn{5}{|c|}{$\frac{10.1 .23}{10.1 .24}$}} \\
\hline & & & & \\
\hline \multicolumn{5}{|l|}{$\frac{10.1 .24}{10.1 .25}$} \\
\hline \multicolumn{5}{|l|}{10.1 .26} \\
\hline \multicolumn{5}{|l|}{ FINAL ATP/OTP } \\
\hline \multirow{2}{*}{\multicolumn{5}{|c|}{\begin{tabular}{|l|}
0.1 .27 \\
10.128 \\
\end{tabular}}} \\
\hline & & & & \\
\hline \multicolumn{5}{|l|}{10.1 .29} \\
\hline \multicolumn{5}{|l|}{10.1 .30} \\
\hline 10.1 .31 & $<115 \mathrm{~dB} C$ at site & & & \\
\hline For outer coverage: & See sound level sheet & attached & & \\
\hline \multicolumn{5}{|l|}{10.1 .32} \\
\hline \multicolumn{5}{|l|}{10.1 .33} \\
\hline \multicolumn{5}{|l|}{10.1 .34} \\
\hline \multicolumn{5}{|l|}{10.1 .35} \\
\hline \multicolumn{5}{|l|}{10.1 .36} \\
\hline \multirow{2}{*}{\multicolumn{5}{|c|}{\begin{tabular}{|l|}
10.1 .37 \\
10.38
\end{tabular}}} \\
\hline & & & & \\
\hline$\frac{10.1 .38}{10.1 .39}$ & & & & \\
\hline \multicolumn{5}{|l|}{10.1 .40} \\
\hline 10.1 .41 & & & & \\
\hline 10.1 .42 & & & 7 & $4 / 14 / 94$ \\
\hline
\end{tabular}


NN HNF-2502, Rev. 0

SOUND LEVEL SHEET FOR:

HNF-SD-L274-ATR-002, Rev 0

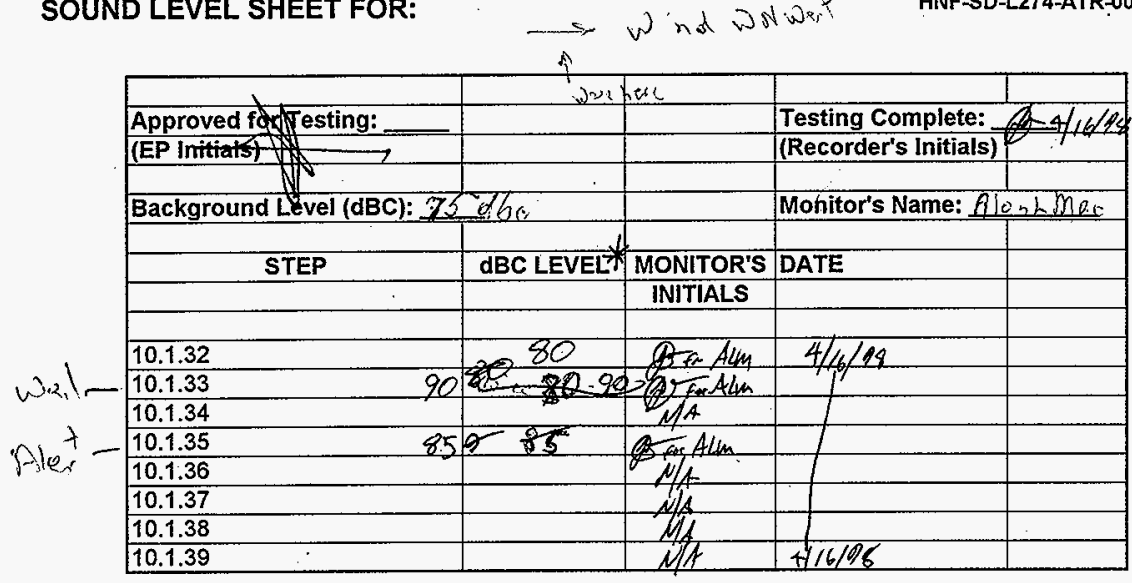

* See note or pace AB.

ATR2W.XLS, 3/21/97

Page: A12 of 22 
DATA SHEET FOR: 650858

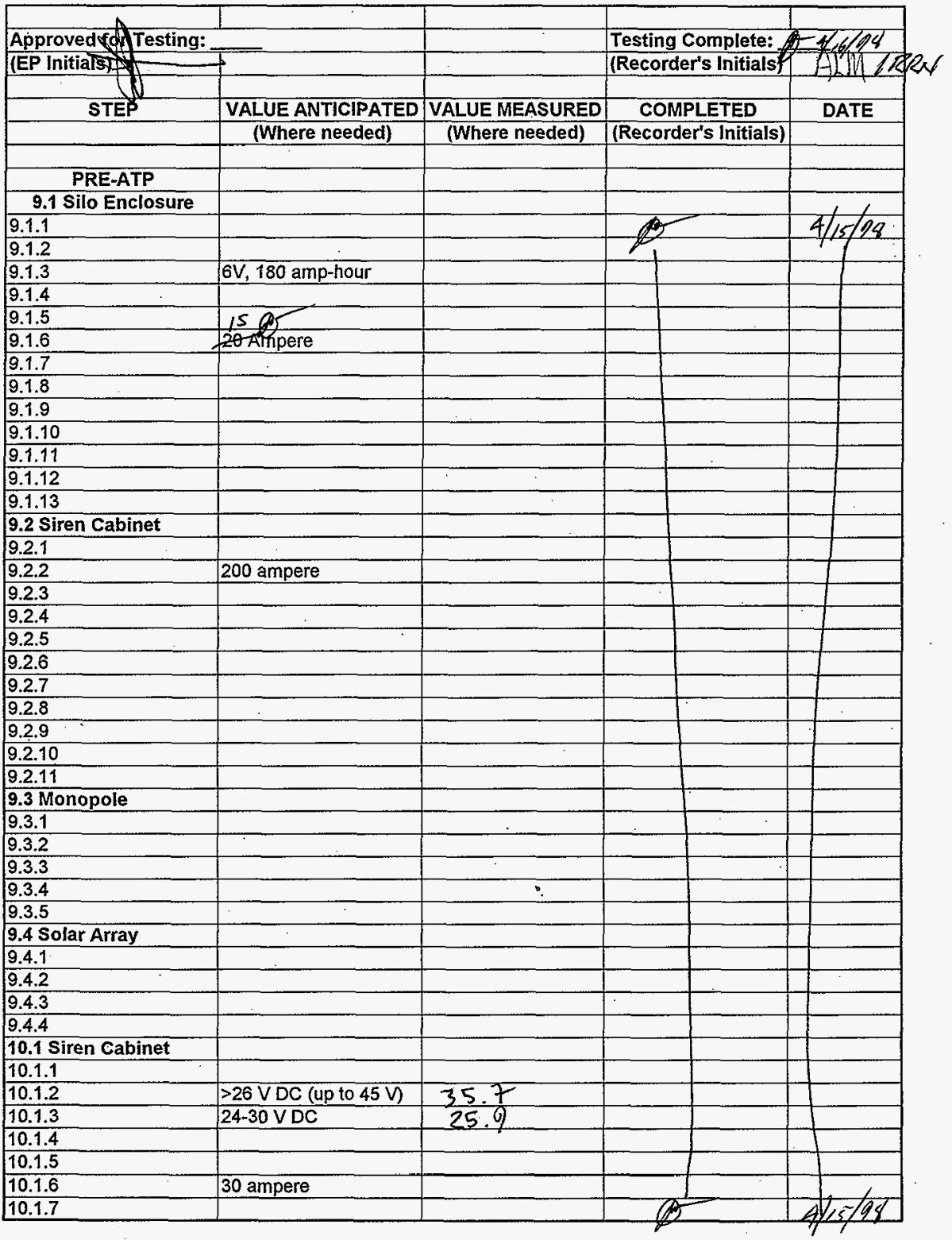




\begin{tabular}{|c|c|c|c|c|}
\hline \multirow{2}{*}{\multicolumn{5}{|c|}{\begin{tabular}{|l|}
10.1 .8 \\
10.1 .9 \\
\end{tabular}}} \\
\hline & & & & \\
\hline \multicolumn{5}{|l|}{10.1 .10} \\
\hline \multicolumn{5}{|l|}{10.1 .11} \\
\hline \multirow{2}{*}{\multicolumn{5}{|c|}{\begin{tabular}{|l|}
10.1 .12 \\
10.13
\end{tabular}}} \\
\hline \multicolumn{4}{|l|}{\begin{tabular}{|l|}
0.1 .13 \\
\end{tabular}} & \\
\hline \multicolumn{5}{|l|}{\begin{tabular}{|l|}
10.1 .14 \\
\end{tabular}} \\
\hline \\
\hline 10.1 .16 & & & & \\
\hline \multicolumn{5}{|l|}{10.1 .17} \\
\hline \multicolumn{5}{|l|}{10.1 .18} \\
\hline \multicolumn{5}{|l|}{10.1 .19} \\
\hline 10.1 .20 & Test director to provide & message content. & & \\
\hline \multicolumn{5}{|c|}{ 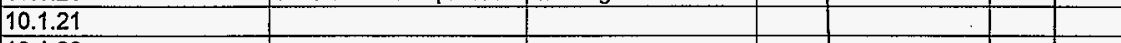 } \\
\hline \multicolumn{5}{|l|}{10.1 .22} \\
\hline \multicolumn{5}{|l|}{ 10.1.23 } \\
\hline \multirow{2}{*}{\multicolumn{5}{|c|}{\begin{tabular}{|l|l|}
10.1 .24 \\
10.1 .25
\end{tabular}}} \\
\hline & & & & \\
\hline \multicolumn{5}{|l|}{10.1 .26} \\
\hline \multicolumn{5}{|l|}{ FINAL ATP/OTP } \\
\hline \multirow{2}{*}{\multicolumn{5}{|c|}{\begin{tabular}{|l|l|}
10.1 .27 \\
0.128
\end{tabular}}} \\
\hline & & & & \\
\hline \multicolumn{5}{|l|}{10.1 .29} \\
\hline \multicolumn{5}{|l|}{10.1 .30} \\
\hline 10.1 .31 & $\angle 115 \mathrm{~dB} C$ at site & & & \\
\hline For outer coverage: & See sound level sheet & attached & & \\
\hline \multicolumn{5}{|l|}{10.1 .32} \\
\hline \multirow{2}{*}{\multicolumn{5}{|c|}{\begin{tabular}{|l|}
10.1 .33 \\
101.34
\end{tabular}}} \\
\hline \multirow{2}{*}{$\frac{10.1 .34}{10.1 .35}$} & & & & \\
\hline & & & & \\
\hline \multicolumn{5}{|l|}{10.1 .36} \\
\hline \multicolumn{5}{|l|}{ 10.1.37 } \\
\hline \multicolumn{5}{|l|}{$\frac{10.1 .38}{101.30}$} \\
\hline \multicolumn{5}{|l|}{10.1 .39} \\
\hline \multicolumn{5}{|l|}{10.1 .40} \\
\hline \multicolumn{5}{|l|}{ 10.1.41 } \\
\hline 10.1 .42 & & & 25 & $4 / 1,1 / 8$ \\
\hline
\end{tabular}


SOUND LEVEL SHEET FOR:

$2-8$

w

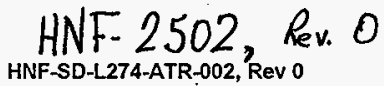

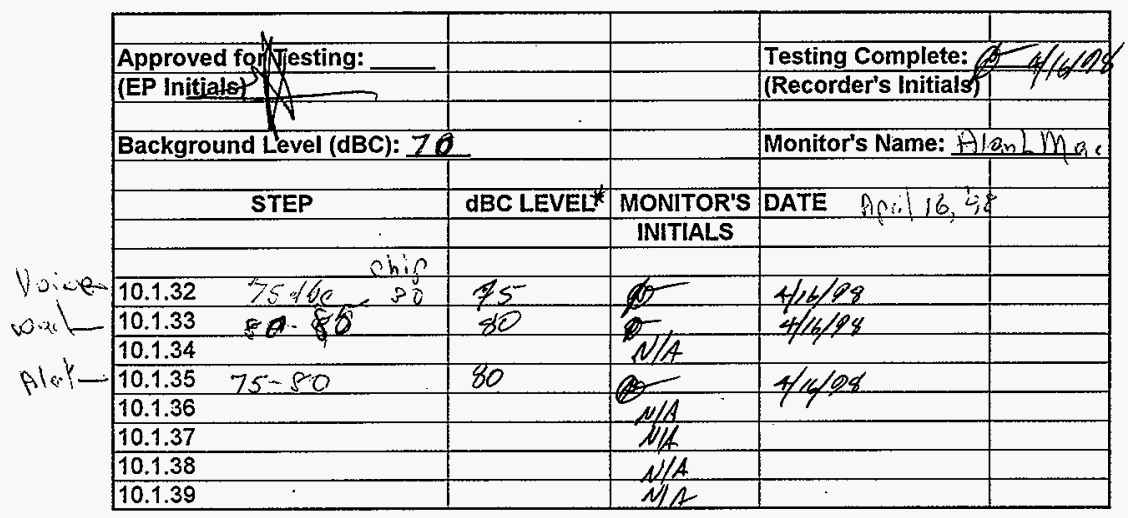

* See note on page $A 3$.

ATR2W.XLS, 3/21/97

Page: $A 15$ of 22 


\begin{tabular}{|c|c|c|c|c|}
\hline & & & \multirow[b]{2}{*}{ Testing Complete: } & \multirow{2}{*}{ diules } \\
\hline \multirow{2}{*}{\multicolumn{2}{|c|}{$\begin{array}{l}\text { Approved fol Testing: } \\
\text { (EP Initiats) }\end{array}$}} & & & \\
\hline & & $\therefore$ & (Recorder's Initials) & 42928 \\
\hline$\frac{V^{\prime}}{\text { STEP }}$ & VALUE ANTICIPATED & VALUE MEASURED & COMPLETED & DATE \\
\hline SIER & (Where needed) & (Where needed) & (Recorder's Initials) & DAIE \\
\hline \multirow{2}{*}{\multicolumn{5}{|c|}{ PRE-ATP }} \\
\hline & & & & \\
\hline \multicolumn{5}{|l|}{ 9.1 Silo Enclosure } \\
\hline 9.1 .1 & & & 24 & 47,5798 \\
\hline \multicolumn{5}{|l|}{9.1 .2} \\
\hline 9.1 .3 & $6 \mathrm{~V}, 180$ amp-hour & & & \\
\hline \multicolumn{5}{|l|}{9.1 .4} \\
\hline 9.1 .5 & 150 & & & \\
\hline 9.1 .6 & 20 Ampere & & & \\
\hline \multicolumn{5}{|l|}{$\frac{9.1 .7}{9.18}$} \\
\hline \multicolumn{5}{|l|}{$\begin{array}{l}9.1 .8 \\
9.1 .9\end{array}$} \\
\hline 9.1 .9 & & & & \\
\hline \multicolumn{5}{|l|}{9.1 .10} \\
\hline \multirow{2}{*}{\multicolumn{5}{|c|}{$\frac{9.1 .11}{9.1 .12}$}} \\
\hline \multirow{2}{*}{\multicolumn{5}{|c|}{$\frac{9.1 .12}{9.1 .13}$}} \\
\hline & & & & \\
\hline \multicolumn{5}{|l|}{ 9.2 Siren Cabinet } \\
\hline \multicolumn{5}{|l|}{$\frac{9.2 .1}{9.22}$} \\
\hline 9.2 .2 & 200 ampere & & & \\
\hline 9.2 .3 & & & & \\
\hline 9.2 .4 & & & & \\
\hline 9.2 .5 & & & & \\
\hline 9.2 .6 & & & & \\
\hline 9.2 .7 & & & & \\
\hline 9.2 .8 & & & & \\
\hline 9.2 .9 & & & & \\
\hline 9.2 .10 & & & & \\
\hline 9.2 .11 & & & & \\
\hline 9.3 Monopole & & & & \\
\hline 9.3 .1 & & & & \\
\hline 9.3 .2 & & & & \\
\hline 9.3 .3 & & & & \\
\hline 9.3 .4 & & $\therefore$ & & \\
\hline 9.3 .5 & & & & \\
\hline 9.4 Solar Array & & & & \\
\hline 9.4 .1 & & & & \\
\hline 9.4 .2 & & & & \\
\hline 9.4 .3 & & & & \\
\hline 9.4 .4 & & & & \\
\hline 10.1 Siren Cabinet & & & & \\
\hline 10.1 .1 & & & & \\
\hline 10.1 .2 & $>26$ VDC (up to $45 \mathrm{~V}$ ) & 40.7 & & \\
\hline 10.1 .3 & 24-30 VDC & 27.4 & & \\
\hline 10.1 .4 & & & & \\
\hline 10.1 .5 & & & & \\
\hline 10.1 .6 & 30 ampere & & $\ldots$ & thothod \\
\hline 10.1 .7 & & & 1 & $4 / 15118$ \\
\hline
\end{tabular}




\section{DATA SHEET FOR:}

\begin{tabular}{|c|c|c|c|c|}
\hline \begin{tabular}{|l|}
10.1 .8 \\
10.19 \\
\end{tabular} & & & 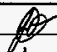 & $4 / 1 5 \longdiv { 0 8 }$ \\
\hline$\frac{10.1 .9}{10.9}$ & & & & \\
\hline 10.1.10 & & & & \\
\hline 10.1.11 & & & & \\
\hline 10.1 .12 & & & & \\
\hline 10.1 .13 & & & & \\
\hline 10.1 .14 & & & & \\
\hline 10.1 .15 & & & & \\
\hline 10.1 .16 & & & & \\
\hline 10.1.17 & & & & \\
\hline 10.1 .18 & & & & \\
\hline 10.1 .19 & & & & \\
\hline 10.1 .20 & Test director to provide & message content. & & \\
\hline 10.1 .21 & & & & \\
\hline 10.1 .22 & & & & \\
\hline 10.1 .23 & & & & \\
\hline 10.1 .24 & & & & \\
\hline 10.1 .25 & & & & \\
\hline 10.1 .26 & & & & \\
\hline FINAL ATP/OTP & & & & \\
\hline 10.1 .27 & & & & \\
\hline 10.1 .28 & & & & \\
\hline 10.1 .29 & & & & \\
\hline 10.1 .30 & & & & \\
\hline 10.1 .31 & $\angle 115 \mathrm{dBC}$ at site & & & \\
\hline For outer coverage: & See sound level sheet & attached & & \\
\hline 10.1 .32 & & & & \\
\hline 10.1.33 & & & & \\
\hline 10.1 .34 & & & & \\
\hline 10.1 .35 & & & & \\
\hline 10.1 .36 & & & & \\
\hline 10.1 .37 & & & & \\
\hline 10.1 .38 & & & & \\
\hline 10.1 .39 & & & & \\
\hline 10.1 .40 & & & & \\
\hline 10.1 .41 & & & & \\
\hline 10.1 .42 & & & $\$ 4$ & $4(15 / 98$ \\
\hline
\end{tabular}




\section{SOUND LEVEL SHEET FOR:}

\begin{tabular}{|c|c|c|c|c|c|}
\hline & & & & & \\
\hline & Approved fol Testing: & & & Testing Complete: & 6416100 \\
\hline & (EP Initiala) I & & & (Recorder's Initials\}) & \\
\hline & W & & & & \\
\hline & Background Level (dBC): & & & Monitor's Name: Ala & inlmac \\
\hline & & & & & \\
\hline & STEP & dBC LEVE[ & MONITOR'S & DATE & \\
\hline & 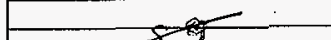 & $\leftarrow$ & INITIALS & & \\
\hline & 84 & -3 & $-\frac{5}{3}$ & & \\
\hline $30^{\circ} !$ & $25,25 c$ & $175 \div 20 \%$ & $\cos 4 \mathrm{Alm}$ & $4 / 6198$ & \\
\hline $300^{\circ} !=6$ & $80.83 d b c$ & 80202 & OStalun & $1 / 16198$ & \\
\hline let. & \begin{tabular}{|l|l|}
10.1 .34 \\
10.25
\end{tabular} & & NAL & 1101 & \\
\hline & $\frac{10.1 .35}{10.1 .26}$ & $80 f \theta=$ & fectum & Al16) & \\
\hline & 10.1.36 & & W/A & & \\
\hline & 10.1 .37 & & $M A$ & & \\
\hline & 70.7 .38 & & N/A & & \\
\hline & 10.1 .39 & & $N / F$ & & \\
\hline
\end{tabular}

* See note on page A3. 
DATA SHEET FOR: $S 10$

\begin{tabular}{|c|c|c|c|c|}
\hline \multicolumn{2}{|l|}{ Approved fo Testing: } & & \multirow{2}{*}{\multicolumn{2}{|c|}{$\begin{array}{l}\text { Testing Complete: } \\
\text { (Recorder's Initials) }\end{array}$}} \\
\hline (EP Initia & & & & \\
\hline$N$ & & & & \\
\hline STEP & VALUE ANTICIPATED & VALUE MEASURED & COMPLETED & DATE \\
\hline & (Where needed) & (Where needed) & (Recorder's Initials) & \\
\hline & & & & \\
\hline PRE-ATP & & & $\not$ & \\
\hline 9.1 Silo Enclosure & & & ESC & $4 / 15 / 98$ \\
\hline 9.1 .1 & 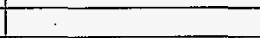 & & eRd & \\
\hline 9.1 .2 & . & & $\angle \mathbb{O}$ & \\
\hline 9.1 .3 & $6 \mathrm{~V}, 180$ amp-hour & & Eed & \\
\hline 9.1 .4 & & & 212 & \\
\hline 9.1 .5 & ${ }_{15} \operatorname{RR} 4 / \mathrm{s} / \mathrm{gB}$ & & $\mathbb{R}$ & \\
\hline 9.1 .6 & 20 Ampere & & 22 & \\
\hline 9.1 .7 & & & RER & \\
\hline 9.1 .8 & & & $2 /$ & \\
\hline 9.1 .9 & & & Zne & \\
\hline 9.1 .10 & & & RKA & \\
\hline 9.1 .11 & & & & $T$ \\
\hline 9.1 .12 & & $\because$ & & 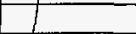 \\
\hline 9.1 .13 & & & 12 & $\checkmark$ \\
\hline 9.2 Siren Cabinet & & & 2 & $4 / 15 / 28$ \\
\hline 9.2 .1 & & & 122 & \\
\hline 9.2 .2 & 200 ampere & & Lex & \\
\hline 9.2 .3 & & & 72 & \\
\hline 9.2 .4 & & & $R$ & \\
\hline 9.2 .5 & & & & \\
\hline 9.2 .6 & & & $\bar{K}$ & \\
\hline 9.2 .7 & & & 2 & \\
\hline 9.2 .8 & & & 25 & \\
\hline 9.2 .9 & & & $\mathbb{k}$ & \\
\hline 9.2 .10 & & & $\not E R$ & $i$ \\
\hline 9.2 .11 & & & REC & $\sqrt{1}$, \\
\hline 9.3 Monopole & & & ERत & 4hotg: \\
\hline $9,3.1$ & & & 1 & 1 \\
\hline 9.3 .2 & & & & \\
\hline 9.3 .3 & & & & \\
\hline 9.3 .4 & & $\because$ & & \\
\hline 9.3 .5 & & & $\sqrt{r}$ & $\Psi$ \\
\hline 9.4 Solar Array & & & 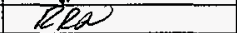 & $410 / 28$ \\
\hline 9.4 .1 & & & 102 & 1 \\
\hline 9.4 .2 & & & 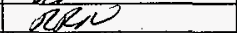 & \\
\hline 9.4 .3 & & & $R 2 N 1$ & 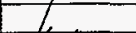 \\
\hline 9.4 .4 & & & $\angle 2 R$ & 415798 \\
\hline 10.1 Siren Cabinet & & & 4 & \\
\hline 10.1 .1 & & & 2 & \\
\hline 10.1 .2 & $>26 \mathrm{VDC}(\mathrm{up}$ to $45 \mathrm{~V}$ ) & $41.02 \sqrt{ } 0 C$ & & $4 / 15798$ \\
\hline 10.1 .3 & 24-30 VDC & 27.2 vDC & $12 \pi$ & 4715798 \\
\hline 10.1 .4 & & & & $4 \times-6$ \\
\hline 10.1 .5 & & & & 7 \\
\hline 10.1 .6 & 30 ampere & & & 2 \\
\hline 10.1 .7 & & & 女 & $415 / 98$ \\
\hline
\end{tabular}


DATA SHEET FOR: $S / O$

\begin{tabular}{|c|c|c|c|c|}
\hline \multirow{2}{*}{\begin{tabular}{|l|}
10.1 .8 \\
10.1 .9 \\
\end{tabular}} & & & tes & $4 / 15 / 88$ \\
\hline & & & & \\
\hline \multicolumn{5}{|l|}{10.1 .10} \\
\hline \multirow{2}{*}{\multicolumn{5}{|c|}{$\frac{10.1 .11}{10.1 .12}$}} \\
\hline & & & & \\
\hline \multicolumn{5}{|l|}{10.1 .13} \\
\hline \multicolumn{5}{|l|}{10.1 .14} \\
\hline \multicolumn{5}{|l|}{10.1 .15} \\
\hline \multirow{2}{*}{\multicolumn{5}{|c|}{\begin{tabular}{|l|}
10.1 .16 \\
10.117
\end{tabular}}} \\
\hline & & & & \\
\hline \multicolumn{5}{|l|}{10.1 .18} \\
\hline \multicolumn{5}{|l|}{10.1 .19} \\
\hline 10.1 .20 & Test director to provide & message content. & & \\
\hline \multicolumn{5}{|c|}{ - } \\
\hline \multicolumn{5}{|l|}{10.1 .22} \\
\hline \multirow{2}{*}{\multicolumn{5}{|c|}{$\frac{10.1 .23}{10.124}$}} \\
\hline & & & & \\
\hline \multicolumn{5}{|l|}{10.1 .25} \\
\hline \multicolumn{5}{|l|}{10.1 .26} \\
\hline \multirow{2}{*}{\multicolumn{5}{|c|}{ FINAL ATP/OTP }} \\
\hline & & & & \\
\hline \multicolumn{5}{|l|}{10.1 .28} \\
\hline \multicolumn{5}{|l|}{10.1 .29} \\
\hline \multirow{2}{*}{\multicolumn{5}{|c|}{$\frac{10.1 .30}{10.1 .31}$}} \\
\hline \begin{tabular}{|l|}
10.1 .31 \\
\end{tabular} & $<115 \mathrm{~dB} C$ at site & & & \\
\hline For outer coverage: & See sound level sheet & attached & & \\
\hline \multicolumn{5}{|l|}{10.1 .32} \\
\hline \multicolumn{5}{|l|}{10.1 .33} \\
\hline \multirow{2}{*}{\multicolumn{5}{|c|}{$\frac{10.1 .34}{10.125}$}} \\
\hline \multirow{2}{*}{\multicolumn{2}{|c|}{$\frac{10.1 .35}{10.1 .36}$}} & & & \\
\hline & & & & 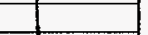 \\
\hline \multicolumn{5}{|l|}{10.1 .37} \\
\hline \multicolumn{5}{|l|}{10.1 .38} \\
\hline \multicolumn{5}{|l|}{10.1 .39} \\
\hline 10.1 .40 & & & & 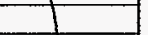 \\
\hline 10.1 .41 & & & & A \\
\hline 10.1 .42 & & & F & 41,5488 \\
\hline
\end{tabular}




\begin{tabular}{|c|c|c|c|c|c|}
\hline & $\Lambda$ & & & & \\
\hline & Approved for esting: & & & \begin{tabular}{|l|} 
Testing Complete: \\
(Recorder's Initials \\
\end{tabular} & $40 / 16 / 40$ \\
\hline & (EP Initietet & & & (Recorder's Initials) & \\
\hline & Background Level (dBC): 6 & $\mathrm{OP}$ & & Monitor's Name: $A$ & antima \\
\hline & & & & & \\
\hline & STEP & dBC LEVEE & MONITOR'S & DATE & \\
\hline & & & INITIALS & & \\
\hline & ch:e & 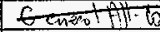 & & & \\
\hline Vo: & $70+75$ & $75 \div 2 \cdot 25$ & $=\Phi 5 A C M$ & $\neq+16498$ & \\
\hline$\omega_{0,1}-$ & $80=35+$ & $8080-557$ & ar Allm. & 416,08 & \\
\hline & 10.1 .34 & & W/A & & \\
\hline Alex... & $80-85+$ & 80 & (1) $x+14 m$ & $4 \longdiv { 1 6 1 9 8 }$ & \\
\hline & 10.1 .36 & & NIA & & \\
\hline & 10.1.37 & & $M / A$ & & \\
\hline & 10.1 .38 & & N/4 & & \\
\hline & 10.1 .39 & & NitA & & \\
\hline
\end{tabular}

* See nde an page $A 3$. 
DATA SHEET FOR: Test Set \& Ruse Station

\begin{tabular}{|c|c|c|c|c|}
\hline \multirow{2}{*}{\multicolumn{2}{|c|}{ Approved fo Testing: }} & & \multirow{3}{*}{\multicolumn{2}{|c|}{\begin{tabular}{|l|l|} 
Testing Complete: \\
(Recorder's Initials) & 4
\end{tabular}}} \\
\hline & & & & \\
\hline 1 & & & & \\
\hline STEP & VALUE ANTICIPATED & VALLE MEASURED & COMPLETED & DATE \\
\hline & (Where needed) & (Where needed) & (Recorder's Initials) & \\
\hline 11.1 TEST SET ATP & 1 & & & \\
\hline 11.1 & 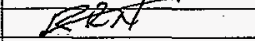 & $12 \pi$ & Iesents & 4) $16 / \mathrm{s}$ \\
\hline 12.1 TEST SET OTP & & & & या1दीवर \\
\hline 12.1.1. & & 10 & & 416498 \\
\hline 12.1 .2 . & & 215 & & \\
\hline 12.1 .3 & & & & \\
\hline 12.1 .4 & & & & \\
\hline 12.1 .5 & & & & T \\
\hline \begin{tabular}{|l|}
2.1 .6 \\
1.7
\end{tabular} & & & & \\
\hline 12.1 .7 & & & & $y$ \\
\hline $12.1 .8^{\circ}$ & & & ERA & प/ $16 / 85$ \\
\hline 13.1 BASE STATION ATP & & & 1 & \\
\hline 13.1.1. & & & & 7 \\
\hline 13.1 .2 & & & & \\
\hline 13.1.3. & & & & \\
\hline 14.1 BASE STATION OTP & & & & \\
\hline 14.1 .1 & & & & \\
\hline 14.1 .2 & & & & \\
\hline 14.1.3 & & & & \\
\hline 14.1.4 & & & & \\
\hline 14.1.5 & & & & \\
\hline$\frac{14.1 .6}{1417}$ & & & $\mathrm{R}^{2} \mathrm{~N}$ & No \\
\hline 14.1.7 & & & & 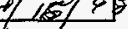 \\
\hline
\end{tabular}

